Institut für Makroökonomie und Konjunkturforschung Macroeconomic Policy Institute

\title{
Money, fiscal policy, and interest rates: A critique of Modern Monetary Theory
}

\author{
January 2013
}

\begin{abstract}
This paper excavates the set of ideas known as modern monetary theory (MMT). The principal conclusion is that the macroeconomics of MMT is a restatement of elementary well-understood Keynesian macroeconomics. There is nothing new in MMT's construction of monetary macroeconomics that warrants the distinct nomenclature of MMT. Moreover, MMT over-simplifies the challenges of attaining non-inflationary full employment by ignoring the dilemmas posed by Phillips curve analysis; the dilemmas associated with maintaining real and financial sector stability; and the dilemmas confronting open economies. Its policy recommendations also rest on over-simplistic analysis that takes little account of political economy difficulties, and its interest rate policy recommendation would likely generate instability. At this time of high unemployment, when too many policymakers are being drawn toward mistaken fiscal austerity, MMT's polemic on behalf of expansionary fiscal policy is useful. However, that does not justify turning a blind eye to MMT's oversimplifications of macroeconomic theory and policy.
\end{abstract}

Keywords: modern monetary theory, money financed budget deficits, fiscal policy.

JEL Classication: E00, E02, E10, E12, E24, E40, E58, E62, E63

\footnotetext{
${ }^{1}$ Thomas I. Palley, New America Foundation, Washington DC,

E-mail: mail@thomaspalley.com
} 


\title{
Money, fiscal policy, and interest rates: A critique of Modern Monetary Theory
}

\begin{abstract}
This paper excavates the set of ideas known as modern monetary theory (MMT). The principal conclusion is that the macroeconomics of MMT is a restatement of elementary well-understood Keynesian macroeconomics. There is nothing new in MMT's construction of monetary macroeconomics that warrants the distinct nomenclature of MMT. Moreover, MMT over-simplifies the challenges of attaining non-inflationary full employment by ignoring the dilemmas posed by Phillips curve analysis; the dilemmas associated with maintaining real and financial sector stability; and the dilemmas confronting open economies. Its policy recommendations also rest on over-simplistic analysis that takes little account of political economy difficulties, and its interest rate policy recommendation would likely generate instability. At this time of high unemployment, when too many policymakers are being drawn toward mistaken fiscal austerity, MMT's polemic on behalf of expansionary fiscal policy is useful. However, that does not justify turning a blind eye to MMT's oversimplifications of macroeconomic theory and policy.
\end{abstract}

Keywords: modern monetary theory, money financed budget deficits, fiscal policy.

JEL reference: E00, E02, E10, E12, E24, E40, E58, E62, E63.

\author{
Thomas I. Palley \\ Independent Economist \\ Washington, D.C. \\ Mail@thomaspalley.com
}

January 2013

\section{Introduction}

This paper excavates the set of ideas known as modern monetary theory (MMT). MMT is a collection of thoughts about the origins of money, the source of value of fiat money, and the nature of the financial constraint on government. It also advances a number of policy recommendations regarding use of money financed budget deficits, interest rate policy, and having government act as employer of last resort (ELR). MMT is significantly associated with economists Randall Wray, Stephanie Kelton, and Mathew 
Forstater of the University of Missouri at Kansas City, along with financier Warren Mosler. Wray (1998) provides the most comprehensive statement of MMT.

The principal conclusion of the paper is that the macroeconomics of MMT is a restatement of elementary well-understood Keynesian macroeconomics. There is nothing new in MMT's construction of monetary macroeconomics that warrants the distinct nomenclature of MMT. Moreover, MMT over-simplifies the challenges of attaining noninflationary full employment by ignoring the dilemmas posed by Phillips curve analysis; the dilemmas associated with maintaining real and financial sector stability; and the dilemmas confronting open economies. This tendency to over-simplify results in poorly conceived policy recommendations, especially for developing countries. Furthermore, MMT policy recommendations take little account of political economy difficulties.

At this time of high unemployment, assessing MMT is difficult. On one hand, MMT's policy polemic on behalf of expansionary fiscal policy is very useful at a time when too many policymakers are being drawn toward mistaken fiscal austerity. On the other hand, one should not turn a blind eye to MMT's oversimplifications of macroeconomic theory and policy.

\section{MMT and the origins and value of sovereign fiat money}

The core of MMT concerns how government issued fiat money (i.e. sovereign fiat money) relaxes the financial constraint on government and opens space for policy. That places sovereign fiat money at the center of the story.

The MMT approach to sovereign fiat money is the Chartalist approach developed by Knapp (1924), which was also accepted by Keynes (1930). Chartalist theory maintains 
government issued fiat money has value because governments demand taxes be paid in sovereign money, thereby creating public demand it. ${ }^{1}$

This idea that the demand for sovereign money is in part due to the obligation to use it to pay taxes is uncontroversial. For instance, James Tobin (1998, p.27), one of the foremost neo-Keynesians, writes in his textbook (co-authored with Steven Golub): ${ }^{2}$

"By its willingness to accept a designated asset in settlement of taxes and other obligations, the government makes that asset acceptable to any who have such obligations, and in turn to others who have obligations to them, and so on."

However, in addition to accepting the Chartalist explanation of money, Keynes and Tobin also accepted money derives value from its use as medium of exchange, unit of account, and store of value. These features supported the development of money, though money was in turn was captured by governments as part of state building and tax collection. Moreover, these features continue to impact the evolution of money, as reflected in the development of e-monies such as debit cards. From this perspective, state money is one form of money that is in perpetual competition with other forms of money, and the boundary of use fluctuates with legal and technological developments. However, state money is the highest form of money in that it can be used to pay tax obligations and it is also generally acceptable for discharge of private debts.

Unfortunately, MMT sets up unnecessary controversy by asserting that the obligation to pay taxes is the exclusive reason for the development of money. Thus, Wray (2012, p.2) writes dismissively of other arguments regarding the development of money:

"We all know the usual approach to money, that begins with the fantasized story about barter, the search for an efficient medium of exchange,...."

\footnotetext{
1 Wray (1998, chapter 2) provides a thorough and concise discussion of Chartalist theory.

2 Wray (1998) cites this quote but it is buried in the last footnote (number 16) of his chapter on Chartalism.
} 
Indeed, he goes further to claim that the obligation to pay taxes is the only reason for the development of markets:

"Why did markets develop? Not to barter what you have but don't want, but rather to obtain the means of debt (tax) settlement (ibid., p.6)."

The critique of this extreme MMT perspective is succinctly stated by Rochon and Vernengo (2003, p.57):

"Sovereignty, understood as the power to tax and to collect in the token of choice, is not the main explanation for the existence of money, even if modern money is ultimately chartal money".

In many regards, these differences over the origins of money are peripheral to the main arguments of MMT, especially as all agree state money is Chartal. That said, they reveal two characteristics of MMT that hold for other issues. The first is the tendency to oversimplification. The second is a polemic whereby over-simplified re-statement of theory is represented as if it were new theory through the nomenclature of "MMT". 3

\section{MMT and the institutional arrangement between fiscal and monetary authorities}

The central macroeconomic policy claim of MMT is that sovereign fiat money changes the nature of the financial constraint on government. In particular, there is no need for government to raise taxes in advance of spending as spending can now be financed in advance of taxes by having the central bank "print" (i.e. create) money. This ability to print money also explains why governments that issue debt in their own currency need never default. That is because central banks can always print money to pay

\footnotetext{
${ }^{3}$ For instance, Michael Hoexter (2013), a leading contributor to the MMT website New Economic Perspectives, writes: "One of the components of macroeconomic management recommended by Keynes but theorized only later by Modern Money Theorists was ending the gold standard and transitioning to a fiat currency.... Abba Lerner's functional finance and later Modern Money Theory (MMT) have been the theories of fiat currency which have as yet not been self-consciously utilized within government policy or integrated into the mainstream economic teaching which still views money as a commodity among other commodities and not what it has been now for many years, a fiat money monopoly." MMT claims in this vein are self-promoting and false.
} 
debt interest and principal as government debt is just a promise to make predetermined payments of sovereign money.

Once again, all of these claims are widely understood and acknowledged. With regard to the capacity to finance spending without recourse to taxes this is easily seen via the government budget restraint given by

(1) $\mathrm{G}-\mathrm{T}=\theta+\beta$

$\mathrm{G}=$ government spending, $\mathrm{T}=$ net tax revenues after transfers and interest payments, $\theta=$ amount of budget deficit financed by issuing high-powered (sovereign) money, and $\beta=$ amount of budget deficit financed by selling government bonds. This restraint is a flowstock accounting relationship and not a budget constraint of the sort confronted by households. The former is fundamentally different from the latter because households do not have the option of issuing money that is accepted as the means of payment. ${ }^{4}$ For instance, setting $\mathrm{T}=0$ and assuming zero bond financing (i.e. $\beta=0$ ), yields $\mathrm{G}=\theta$.

The budget restraint was a key feature of neo-Keynesian analysis of fiscal policy (see for example Christ, 1969; Blinder and Solow, 1973, and Tobin and Buiter, 1976) and it shows clearly that governments which have the power to issue sovereign money can always finance deficits without recourse to taxes. The critical question is not whether government can finance spending without taxes. Everybody knows it can. Instead, the question is what are the macroeconomic consequences of doing so and should government do so? MMT analysis is seriously deficient in answering these questions and

\footnotetext{
${ }^{4}$ Neo-Keynesians were fully aware of this difference. For instance, Tobin and Haliassos (1990, p.899) describe the language of "budget restraint" as a "misnomer" and they prefer to call it a "budget flow identity", reflecting its purely accounting character.
} 
constitutes an analytic step back compared to the earlier neo-Keynesian analyses of Blinder and Solow (1973) and Tobin and Buiter (1976). ${ }^{5}$

As regards government's ability to always repay debt if it so chooses, that too is clear from the budget restraint. Repaying debt implies $\beta_{\text {Repayment }}<0$, and this can always be financed by setting $\theta_{\text {Repayment }}>0$ such that $\theta_{\text {Repayment }}+\beta_{\text {Repayment }}=0$. It is not just neoKeynesians who understand this. For instance, former Federal Reserve Chairman Alan Greenspan (1997, p.2) writes:

"That all of these claims on government are readily accepted reflects the fact that a government cannot become insolvent with respect to obligations in its own currency. A fiat money system, like the one we have today, can produce such claims without limit."

Finally, the government budget restraint shows the accounting whereby governments that issue sovereign money can, in principle, finance spending by printing money. However, that also requires a particular institutional arrangement between the fiscal authority and the central bank. This institutional issue has been raised by Lavoie (2011) and Fiebiger (2012), and Lavoie terms it the "consolidation" assumption. Simple T-accounting shows that the central bank must be willing to provide the government with the initial money balances to finance its spending. In effect, that implies the fiscal authority and central bank act as if they were a consolidated single actor. ${ }^{6}$

In my view, this is not the main issue in the critique of MMT, but it is still an important issue. Many countries have chosen to separate their central bank and fiscal

\footnotetext{
${ }^{5}$ Judging by the absence of citation references (see for instance, Wray, 1998), MMT-ers appear to be unaware of this earlier neo-Keynesian literature.

${ }^{6}$ Lavoie (2011) and Fiebiger (2012) focus on the fiscal authority - central bank relationship but there is also the issue of monetary policy. Even when the central bank and fiscal authority are not consolidated, it can look as if they are. The effect of budget deficits on the money supply and interest rates depends critically on the stance of monetary policy. Thus, if an independent central bank decides to fully accommodate fiscal policy that will produce an outcome that looks as if the central bank and fiscal authority are consolidated. MMT therefore implicitly assumes both consolidation and full accommodation by monetary policy.
} 
authority. That separation involves complete and total independence in the case of the European Central Bank (ECB). As regards the U.S. Federal Reserve, there is arms-length decision making independence but the Federal Reserve is accountable to Congress. The pendulum, regarding the degree of independence, shifts with the political and economic times. Over the last thirty years, spurred by the political and intellectual dominance of neoliberal economic ideas, it has swung toward increased independence. In the 1960s and 1970s the Bank of England was directly under the control of the Chancellor of the Exchequer. In the 1990s that arrangement was changed and the Bank was given armslength decision making independence, subject to being accountable to the Chancellor and aiming for targets that are mutually agreed with the Chancellor.

The important point is institutional arrangements vary across countries owing to differences in country choices. This is an important issue of political economy. MMT-ers are dismissive of this political economy and simply assume there is and should be full consolidation of the fiscal authority and central bank.

My own preference is for greater consolidation and less central bank independence, but I would stop short of full consolidation. Paraphrasing the words of former Federal Reserve Chairman William McChesney Martin, it is difficult to take away the punchbowl in the middle of the party. That is what the central bank must sometimes do, and it is something politicians may find hard to do and therefore prefer to hand-off to others. $^{7}$ Additionally, politicians may have an incentive to use monetary policy for electoral purposes, potentially giving rise to political business cycles (Nordhaus, 1975). MMT's dismissiveness of these political economy considerations is part of a general

\footnotetext{
${ }^{7}$ My suggested reform of the Federal Reserve System is described in Palley (2012a) and would give the President greater influence over the Federal Reserve.
} 
intellectual weakness regarding political economy that is also visible in its treatment of fiscal policy and the ELR policy proposal, issues which are discussed below.

\section{MMT and macroeconomic theory}

MMT is in essence a restatement of well-understood accounting relations that show the potential to finance budget deficits by printing money. However, accounting relations are not enough to guide policy. There is also need for macroeconomic theory that explains the consequences of fiscal policy under alternative financing arrangements. Here, MMT fails woefully. There is nothing new about its theory, and the theory it uses is simplistic and inadequate for the task. Furthermore, MMT-ers have failed to provide a formal model that explicates their claims.

Given this lack of formal modeling, readers must fend for themselves and the implicit model seems to be the simplest of income-expenditure models. That model is illustrated in Figure 1 which shows the standard Keynesian cross diagram. According to this model, government can push the economy to full employment by increasing government spending $(\mathrm{G})$ or lowering taxes $(\mathrm{T})$ to raise aggregate demand $(\mathrm{AD})$ to a level consistent with full employment output (y") so that

(2) $y=y^{*}=A D(G, T)$

$\mathrm{AD}_{\mathrm{G}}>0, \mathrm{AD}_{\mathrm{T}}<0$

There is no finance constraint on $\mathrm{G}$ because of the capacity to issue sovereign money. However, once the economy reaches full employment output, taxes (T) must be raised to ensure a balanced budget satisfying the condition

(3) $\mathrm{D}=\mathrm{G}-\mathrm{T}\left(\mathrm{y}^{*}, \mathrm{t}\right)=0 \quad \mathrm{~T}_{\mathrm{y}^{*}}>0, \mathrm{~T}_{\mathrm{t}}>0$

This balanced budget condition must be satisfied in order to maintain the value of fiat money. In a no growth economy, having the fiscal authority run persistent money 
financed deficits will cause the money supply to increase relative to GDP, in turn causing inflation. $^{8}$

Figure 1. The macroeconomics of MMT $\left(\mathrm{AD}_{1}<\mathrm{AD}_{2}\right)$.

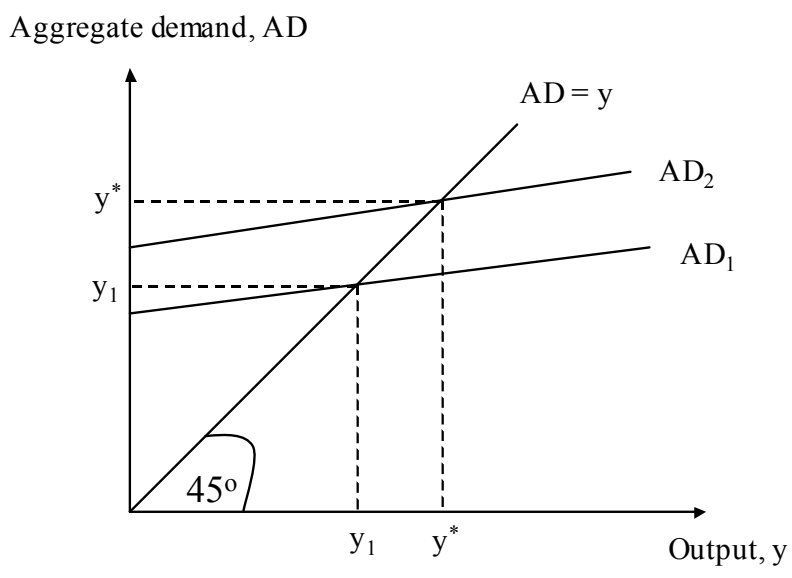

The policy control problem confronting the fiscal authority is to set its policy instruments $(G$ and $t)$ so as to hit its two targets given by $y=y^{*}$ and $D=0$. There are two independent instruments ( $G$ and $t)$ and two targets ( $y$ and $D)$ so the control problem is feasible.

Though not identified by MMT-ers, there is an interesting Tinbergen - Mundell policy instrument assignment problem that requires $\mathrm{G}$ be assigned to the $\mathrm{y}$ target and $\mathrm{t}$ be assigned to the $\mathrm{D}$ target. That is because the government expenditure multiplier is larger than the tax multiplier. Consequently, assigning $t$ to $y$ could cause instability. For instance, suppose $t$ were assigned to $\mathrm{y}$. A fall in autonomous demand would require lower taxes, but that would cause a budget deficit requiring lower $\mathrm{G}$, which would in turn lower $\mathrm{y}$ and require yet lower taxes. The implication is taxes must be used to hit the budget

\footnotetext{
${ }^{8}$ In a growing economy, the fiscal authority can run persistent money financed deficits and still maintain price stability if the implied growth of the money supply equals the rate of growth of real output.
} 
deficit target, while government spending must be used to maintain full employment output.

This assignment requirement has unappreciated policy implications in the current era of fiscal austerity. Many European governments, aided by the IMF, are seeking to return to full employment output with a budget deficit target. Broadly speaking, they appear to be looking to cut taxes to stimulate output and reduce government spending to hit the budget deficit target. That assignment is unstable.

The income-expenditure model with a balanced budget condition (i.e. equations (2) and (3)) appears to constitute the implicit MMT macroeconomic model. We can now turn to critique. The first thing to note is that sovereign money is absolutely central to MMT analysis as it removes the financial constraint on government spending when below full employment output. However, it is absent in the simple income-expenditure model. Let us therefore begin to introduce it.

If the economy is initially away from full employment, assuming an appropriate assignment of instruments, the government should engage in increased money financed deficit spending. Simple Keynesian expenditure multiplier theory then shows that the deficit must increase by

(4) $\Delta \mathrm{D}=[d \mathrm{D} / d \mathrm{G}] \Delta \mathrm{G}=[1-\mathrm{t} / \mathrm{m}] \Delta \mathrm{G}>0$

$\mathrm{m}=1-\mathrm{b}[1-\mathrm{t}]$. Increased government spending always increases the deficit and spending increases do not pay for themselves through increased tax revenues. The only time they pay for themselves is with balanced budget fiscal policy, but that is not the intent of the 
MMT which denies the need to finance deficits with taxes. ${ }^{9}$ In a static economy that means the money supply would keep growing, which must be unsustainable.

Is there a way out of this? The answer is yes and it is provided by the neo-

Keynesian stock - flow consistent ISLM analysis of Blinder and Solow (1973) and Tobin and Buiter (1976). The key is adding a Pigou real balance effect to AD. The budget deficit increases the real high-powered money supply (H/P), creating a real balance effect that increases $\mathrm{AD}$ and eventually pushes the economy to full employment as illustrated in Figure 2. ${ }^{10}$

Figure 2. The MMT macroeconomic framework with a Pigou real balance effect $\left(\mathrm{AD}_{1}<\mathrm{AD}_{2}, \mathrm{H}_{1}<\mathrm{H}_{2}\right)$.

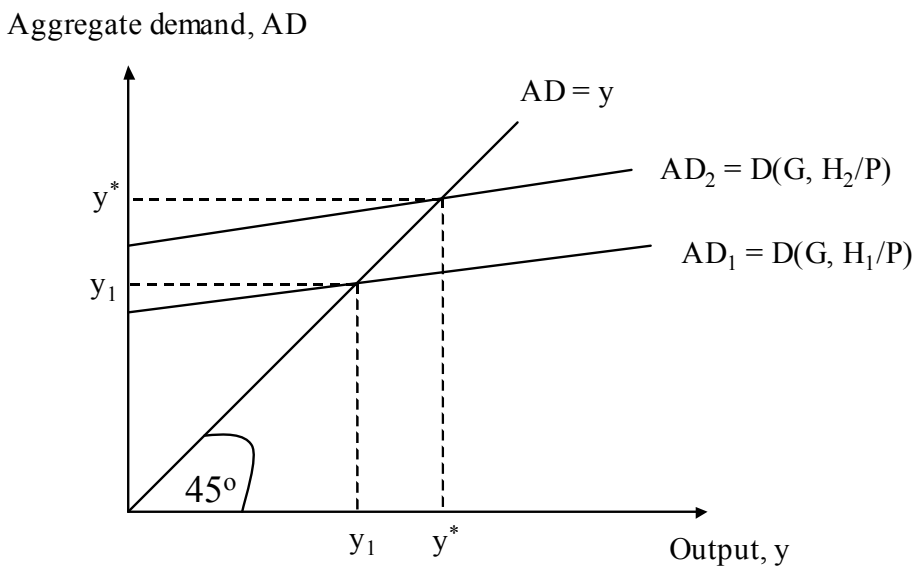

\footnotetext{
${ }^{9}$ Keynesian expenditure multiplier theory also shows that spending cuts must reduce the deficit, counter to claims sometimes seen that they increase deficits. However, spending cuts only do so at massive cost in terms of lost output. That is their true failing.

${ }^{10}$ In terms of the Blinder and Solow (1973) and Tobin and Buiter (1976) models, the MMT experiment is identical to a money financed budget deficit with a constant interest rate. Blinder and Solow (1973) and Tobin and Buiter (1976) actually analyzed fiscal policy under more arduous conditions when the monetary authority holds the high-powered money supply constant. Their analysis shows fiscal policy is still expansionary (though Post Keynesian s would also argue this is a fictional experiment as monetary authorities do not target the high-powered money supply). In both cases the economy settles at a stable equilibrium characterized by a balanced budget $(\mathrm{D}=0)$. The MMT experiment adds the additional requirement that the budget deficit only be balanced when the economy reaches full employment output (y $\left.=\mathrm{y}^{*}\right)$. However, there is nothing theoretically new.
} 
There are several things to notice. First, the macroeconomics of MMT is a primitive version of neo-Keynesian stock-flow consistent ISLM analysis. This ISLM analysis of the effectiveness of fiscal policy is completely unacknowledged in the MMT literature, which is essentially the reinvention of an inferior wheel. Stock - flow consistent ISLM analysis captures almost everything MMT has to say regarding fiscal policy. ${ }^{11}$

Second, introducing the government budget restraint also captures the notion that taxes drive money. ${ }^{12}$ This can be seen from the following simple model of the money market:

(5) $\mathrm{H}^{\mathrm{s}}=\mathrm{H}(\mathrm{y}-\mathrm{T}, \mathrm{i}, \mathrm{k})$

(6) $\mathrm{H}^{\mathrm{s}}=\mathrm{H}_{-1}+\theta+\gamma$

(7) $\theta=\mathrm{G}-\mathrm{T}-\beta$
$\mathrm{H}_{\mathrm{Y}-\mathrm{T}}>0, \mathrm{H}_{\mathrm{i}}<0, \mathrm{H}_{\mathrm{k}}>0$

$\mathrm{i}=$ nominal interest rate, $\mathrm{k}=$ bank reserve requirements, $\gamma=$ open market injections of the

\footnotetext{
${ }^{11}$ MMT-ers' unawareness of this neo-Keynesian ISLM literature reflects a complicated sociology. First, MMT-ers have tended to exhibit an aversion to mathematical modeling on grounds that such modeling is an exercise in fiction. The stock - flow consistent ISLM literature is quite mathematical which may have discouraged MMT-ers from reading it. A second reason is that MMT is an extreme wing of Post Keynesian economics and many Post Keynesians have an allergy to ISLM analysis. MMT-ers suffer an extreme version of that allergy. Rejection of ISLM analysis has become a near-litmus test among many Post Keynesians. Such thinking is misinformed. Stock-flow consistent ISLM analysis is temporary equilibrium analysis (like the income - expenditure model) conducted in output - interest rate space. ISLM's architecture is fine but its detailed specification is subject to meaningful critique, particularly as regards the omission of endogenous money, inside debt, and inside debt effects on AD. This theological rejection of ISLM has done great damage to PK economics by creating unnecessary schism with neo-Keynesians and blinding Post Keynesians to the merits of the ISLM model as a base on which they could have built. Indeed, Post Keynesian economics is now unwittingly re-inventing the stock - flow consistent ISLM model as evidenced by the much cited work of Godley and Lavoie (2007). The principal innovation in their framework is the extension of the stock-flow consistent ISLM model to include endogenous money, inside debt, and inside debt effects on AD.

12 The language of "taxes drive money" is very misleading. What MMT mean is that taxes positively affect the demand for sovereign money. However, taxes are just one factor, not the only factor. Moreover, in an endogenous money system in which the monetary authority targets the overnight interest rate, any demand for sovereign money to pay taxes will be provided by the monetary authority. Consequently, there can never be a shortage of sovereign money to pay taxes.
} 
supply equal money demand. ${ }^{13}$ Equation (6) describes the evolution of the money supply, while equation (7) is a re-arrangement of the government budget restraint.

Substituting equations (6) and (7) into (5) and re-arranging yields

(8) $\mathrm{H}_{-1}+\mathrm{G}-\beta+\gamma=\mathrm{H}(\mathrm{y}-\mathrm{T}, \mathrm{i}, \mathrm{k})+\mathrm{T}$

The left-hand side of equation (8) represents the high-powered money supply which is determined by last period's supply, government spending less that part financed by bond sales, plus open-market purchases of bonds by the central bank. The right-hand side consists of private sector demand for high-powered money plus tax payments so that tax payments increase ("drive") money demand.

Third, the Blinder-Solow (1973) stability analysis of money-financed fiscal policy emphasizes the role of the Pigou real balance effect in closing the budget deficit. Expansionary fiscal policy always increases the budget deficit. Unless policy is reversed, closing the deficit requires increased $\mathrm{AD}$ that raises income and tax revenue. That is accomplished via the Pigou effect that results from the increase in the money supply caused by the deficit. However, as is now being shown by the slow response of the economy to the Federal Reserve's quantitative easing $(\mathrm{QE})$ programs, this effect can be very slow. ${ }^{14}$ Consequently, the increase in the money supply over the duration of the return to full employment can be very large. That poses a significant policy challenge for future financial stability and future inflation that MMT is dismissive of. The next section discusses this and other issues.

\footnotetext{
${ }^{13}$ The money demand function could also include $\mathrm{T}$ as a separate argument with $\mathrm{H}_{\mathrm{T}}>0$.

14 The Federal Reserve's QE programs have directly monetized part of the budget deficit via government bonds purchases. The Federal Reserve has also purchased agency-backed mortgage backed securities (MBS). Since such securities are very close portfolio substitutes for Treasury bonds, their purchase is tantamount to deficit monetization.
} 


\section{Further over-simplifications and omissions of MMT}

The previous section explored the macroeconomic theory behind MMT and showed there is nothing new. In fact, MMT is an inferior rendition of the analysis of money-financed fiscal policy contained in the stock-flow consistent ISLM analysis of Blinder and Solow (1973) and Tobin and Buiter (1976). This section explores some additional critiques.

\section{Prices and inflation.}

The central policy assertion of MMT is the non-existence of financial constraints on government spending below full employment. The claim is government can issue money to finance non-inflationary spending as long as the economy is below full employment. However, though full of boilerplate disclaimers about the need to take account of inflation (see for instance, Wray, 1998), MMT lacks an explicit theory of inflation, how inflation impacts the economy, and how that impact complicates policy.

Once again, the lack of formal modeling requires reading between the lines to try and intuit the MMT approach to inflation. That approach seems to be an "on-off" model in which the economy is initially below full employment and then hits the full employment barrier. That corresponds to an economy with an L-shaped aggregate supply (AS) schedule as shown in Figure 3. Below full employment, the inflation switch is "off" and expansions of AD generate pure output gains with no price level or inflation effects. At full employment, the inflation switch is "on" and expansions of AD generate pure price level increases with no output effects. 
Figure 3. The implicit MMT model of price level and output determination $\left(\mathrm{M}_{0}<\mathrm{M}_{1}<\mathrm{M}_{2}<\mathrm{M}_{3}\right)$.

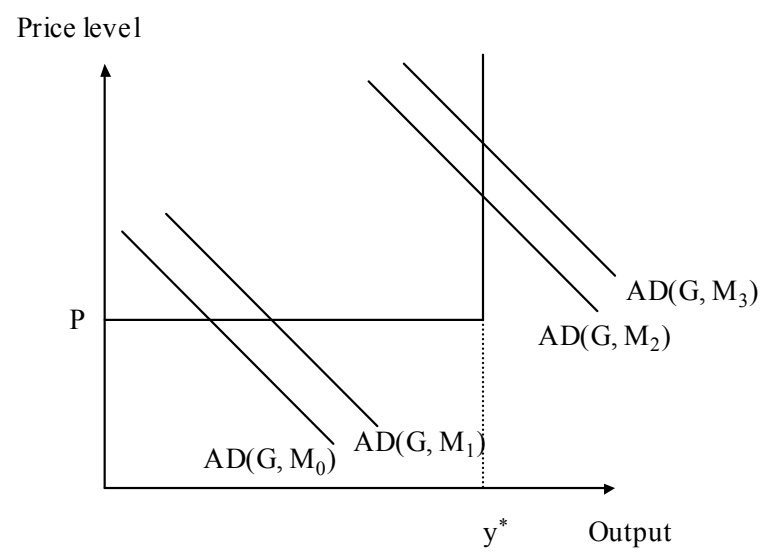

The problem is this is not the way the macro economy works. Instead of a single sector, the economy is better characterized as a multi sector arrangement with some sectors at full employment and other below. In this case, the price and output effects of expanding AD depend on the mix of sector conditions. This is illustrated in Figure 4 for the case of a two sector economy. The AS schedule is horizontal when both sectors are below full employment: it is positively sloped when one sector is below full employment and the other is at full employment; and it is vertical when both are at full employment. The economy's price level - output response therefore depends on the mix of sector conditions. 
Figure 4. The AS schedule for a two sector economy.

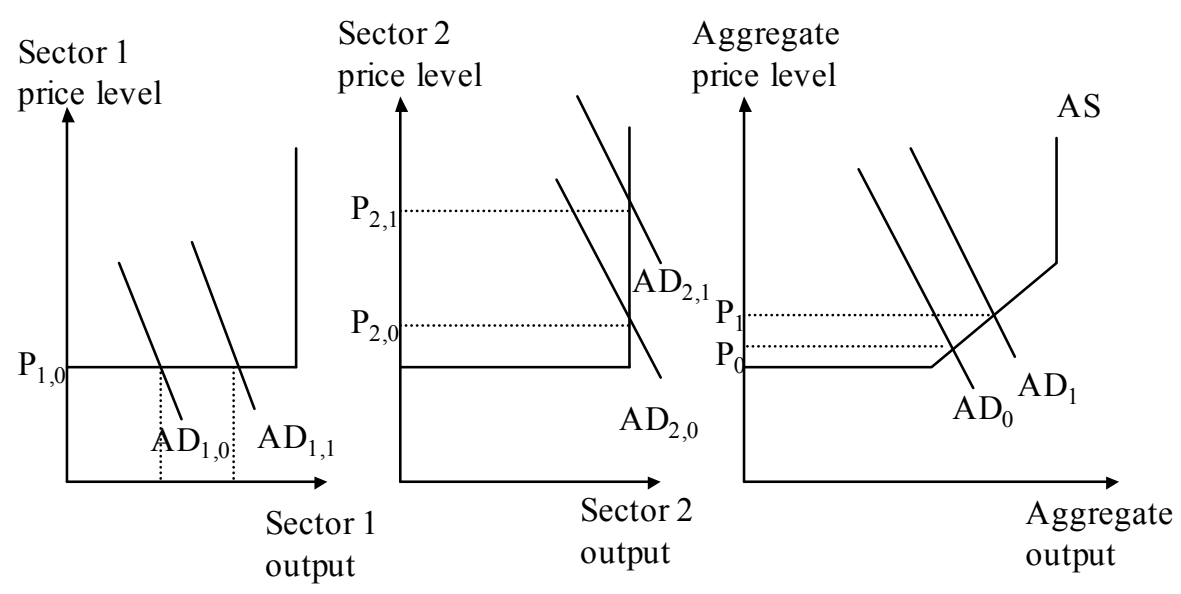

Figure 4 shows that both prices and output increase in response to increased $\mathrm{AD}$ when one sector is below full employment and the other is at full employment. Exactly when prices start to increase will depend on the distribution of sector conditions, and prices may start to increase when aggregate output is quite low if demand is very asymmetrically distributed. This illustrates the difficulty of achieving full employment using aggregate policy instruments.

When converted to a dynamic frame, the price level - output trade-off becomes an inflation - unemployment trade-off captured by a standard Phillips curve of the form (9) $\pi=\mathrm{f}(\mathrm{u})+\lambda \pi^{\mathrm{e}} \quad \mathrm{f}_{\mathrm{u}}<0,0<\lambda<1$ $\pi=$ inflation, $\mathrm{u}=$ unemployment rate, $\lambda=$ coefficient of inflation expectations feedthrough, $\pi^{\mathrm{e}}=$ inflation expectations.

The issue of the Phillips curve trade-off is central to macroeconomics and policy. MMT analysis, based on an aggregate income-expenditure model, offers a false choice of 
unemployment versus full employment with price stability. Though full of boilerplate language about concern with inflation, MMT fails to address the dilemmas posed by the Phillips curve for budget deficit financing policy.

The significance of the Phillips curve is that inflation is not an "off-on" phenomenon. Instead, it will be positive a considerable way away from policymakers' employment target and it is likely to increase as employment approaches the target. Policy needs to take account of this. That may mean changing the composition of deficit financing and shifting away from money finance to bond finance. ${ }^{15} \mathrm{MMT}$ ignores such considerations.

\section{Inflation and money financed budget deficits}

Money financed budget deficits increase the supply of high-powered sovereign money which embodies latent purchasing power. Even if not activated immediately on issue, high-powered money may be activated at a future date and it can be difficult to deactivate it in non-disruptive fashion. Moreover, deactivating it is especially difficult given that MMT advocates abandoning activist interest rate policy (about which more below).

The Phillips curve can be augmented as follows to include the additional inflationary dangers of excessive issue of high-powered money

(10) $\pi=\mathrm{f}(\mathrm{u})+\lambda(\mathrm{h}) \pi^{\mathrm{e}} \quad \mathrm{f}_{\mathrm{u}}<0, \lambda_{\mathrm{h}}>0,0<\lambda(\mathrm{h})<1$

(11) $\pi^{\mathrm{e}}=\pi(\mathrm{h}) \quad \pi_{\mathrm{h}}>0$

$\mathrm{h}=\mathrm{H} / \mathrm{y}^{*}=$ ratio of high-powered money to potential nominal GDP. Increases in the highpowered money ratio potentially impact inflation via two channels, both connected to

\footnotetext{
${ }^{15}$ Phillips curve analysis imposes a trade-off between inflation and unemployment. My own experience of MMT-ers is they apply an extreme discount on inflation and view it as essentially costless economically. In this regard, I have heard a leading proponent of MMT claim inflation below 40 percent is costless.
} 
expectations. First, it may increase the coefficient of inflation expectations, leading to greater feed-through of inflation expectations into the Phillips curve inflation process. Second, it may directly raise inflation expectations.

How powerful these expectation effects are is likely to be highly contextual. In times of deep recession when there is significant excess supply, such effects are likely to be relatively minimal. However, they are likely to become greater as the economy strengthens. Furthermore, these expectation effects may be volatile and subject to unpredictable change associated with shifts of confidence, etc.

Equation (10) is only intended to be illustrative of how high-powered money might affect the Phillips curve inflation process. Formally modeling and predicting inflation is notoriously difficult and the role of liquidity in driving inflation is especially difficult because of the long and variable lags associated with the effects of changes in liquidity. Liquidity may lie inert for long periods and then suddenly become activated by changes in psychology induced by small changes in economic activity.

That is not an argument against expansionary fiscal policy in times of recession, but it is an argument against exclusive reliance on money-financed deficits. Instead, even in times of recession, there are good reasons to use a combination of money- and bondfinanced deficits. The former injects high octane high-powered money, while the latter takes advantage of lower interest rates resulting from recessionary conditions. That means government can finance deficits at relatively low cost and with reduced danger of subsequent liquidity blowback. As the economy moves out of recession, liquidity blowback concerns become even more prominent, speaking to the need to shift the composition of deficit financing toward increased bond financing. 


\section{Financial instability and money financed deficits.}

Future inflation has been the traditional concern of money-financed deficits that generate large liquidity build-ups. The string of asset price bubbles in the 1990s and 2000s that culminated with the financial crisis of 2008 has made economists and policymakers aware of the dangers of asset price bubbles and financial fragility. Those dangers provide another reason for caution about financing deficits with money even in times of weak economic activity, and especially in times of more normal economic activity.

Whereas general price inflation is unlikely in times of weak economic activity, asset price inflation can occur at any time. As with general price inflation, modeling the relation between liquidity build-ups and financial instability is extremely difficult. That

relationship is not mechanical or fixed in form. Instead, liquidity is akin to latent financial energy that can accumulate, leading to greater danger of unanticipated combustion. However, because the danger cannot be deterministically modeled, that does not mean it should be ignored. Yet that appears to be the implicit recommendation in MMT's policy of exclusive reliance on money financing of budget deficits.

\section{Open economy considerations and money financed deficits.}

As with discussion of inflation, MMT writing (again see Wray, 1998) contains much boilerplate cover about the need to take account of open economy and exchange rate concerns, but nowhere is there formal treatment of these considerations and how they might constrain the use of money-financed budget deficits. The reality is, as with inflation, that taking serious account of open economy considerations introduces significant complexities and constraints regarding use of money financed budget deficits. 
Such deficits increase the supply of high powered money and the money created must be willingly held. Some of the increase in supply will be directed to the acquisition of foreign money balances and purchases of imports, which will generate exchange rate depreciation. That in turn can amplify inflation and inflation expectations, and also foster financial instability.

With regard to real output effects, there is a long standing literature, initiated by Krugman and Taylor (1978), about the possibility of contractionary devaluation whereby exchange rate depreciation lowers economic activity. The likelihood of such an outcome depends on the characteristics of the economy such as the price elasticity of import and export demands; the extent of reliance on imports; availability of substitutes for imports; the nature and structure of domestic production; and the extent to which increased import prices feed through into domestic prices.

The exchange rate is also a critical determinant of inflation, especially in Latin American economies that are highly dependent on imported inputs and capital goods. In countries like Brazil, it is the exchange rate rather than capacity utilization that is systematically connected to inflation and inflation expectations. There is a high degree of exchange rate pass-through into the domestic price level. Moreover, inflation expectations tend to be weakly anchored so that exchange rate depreciation can quickly trigger higher inflation expectations that destabilize both the economy and politics. Furthermore, wages tend to be a casualty of such developments as nominal wages tend to lag prices.

Small open economies with histories of high inflation have also shown themselves prone to the phenomenon of currency substitution or "dollarization" whereby 
domestic economic agents abandon the national money in favor of a more stable store of value. Dollarization shows that the store of value property is an important property of money, contrary to MMT denials of the significance of this property. From a public finance perspective, it is costly in terms of lost seignorage revenue. And from a macroeconomic perspective, it can fuel higher inflation via the process described by Cagan (1956), with flight from domestic money in search of other stores of value driving up the velocity money, and thereby generating faster higher inflation.

Finally, there is the problem of the balance of payments constraint on expansionary fiscal policy, which applies to both developing and developed counties. ${ }^{16}$ If fiscal policy succeeds in expanding $\mathrm{AD}$ and income, it will likely cause significant deterioration in the current account. This can be financed via foreign borrowing, but that is rejected by MMT because it exposes countries to future foreign debt problems. Absent a way to finance the current account deficit, financial markets will put pressure on countries to put a "stop" to their budget deficit "go" policies. Attempting to escape the balance of payments constraint via exchange rate depreciation exposes countries to the inflation and financial dislocation effects discussed above. Moreover, the problem is amplified if all countries try to go that route as the result is global competitive devaluation. Parenthetically, the balance of payments constraint was emphasized by Cripps and Godley (1978) but their solution was import controls, which is rejected by MMT.

In sum, the above adverse effects speak to the significant constraints on using money financed budget deficits in open economies. These effects constitute a further

\footnotetext{
${ }^{16}$ My thanks to Esteban Perez for pointing out the balance of payments constraint on expansionary fiscal policy and Wynne Godley's concern with it.
} 
critique of simplistic MMT claims about the ease of attaining non-inflationary full employment.

\section{Other reasons for bond financed deficits}

In addition to the above macroeconomic arguments cautioning against exclusive reliance on money financed deficits, there are also microeconomic efficiency arguments for why government should also use bond finance. A first reason for bond financing is the creation of a default-free financial instrument that can be used to price other privately issued financial instruments. Inflation indexed bonds provide the ultimate risk-free instrument as they are free of both default risk and inflation risk. Given these properties, government bonds are useful to financial intermediaries and financial markets and they help promote financial stability.

A second microeconomic reason for bond finance, implied in the work of Tobin $(1961,1969,1982)$, is that bonds are a closer portfolio substitute for equities and private capital than is high-powered money. The existence of widely-held bonds that the central bank can deal in therefore provides the monetary authority with an effective channel for influencing the cost of private capital without engaging in direct acquisition of private capital. That is desirable as central bank purchases of private capital can easily become a source of subsidy for some and competitive disadvantage to others.

A third microeconomic reason for bond financing is that bonds provide a means of transferring income from future to current generations. ${ }^{17}$ If future generations are expected to be better off (i.e. have higher per capita real income) owing to technological

\footnotetext{
${ }^{17}$ That is because current generations own the bonds and will therefore receive payment made from some combination of future taxes and future money issue.
} 
progress, government bonds provide a way of sharing some of that future bounty with the current generation.

A fourth and final microeconomic reason for bond finance is that much public spending is long-lived. That includes spending on infrastructure, health care, and education. It may therefore make sense to finance such spending with long-term financing that matches financial costs to the stream of benefits. Those who receive the financial benefits thereby contribute to covering the financial costs.

\section{Fiscal policy over-optimism?}

A last issue concerns the long-term effectiveness of fiscal policy. MMT-ers can be labeled "fiscal policy optimists". The same holds for neo-Keynesians. Both believe that expansionary fiscal can shift the economy to full employment and maintain it there, regardless of factors such as the distribution of income. This fiscal policy optimism is open to question.

For neo-Keynesians, counter-cyclical expansionary fiscal policy is viewed as a temporary expedient designed to offset temporary declines in private sector AD resulting from shocks such as slumps in animal spirits. The assumption is animal spirits, perhaps assisted by the pump-priming benefits of policy, will eventually bounce back. The same logic holds for MMT's confidence in fiscal policy.

Other macroeconomic perspectives are less optimistic. Kaleckian macroeconomics emphasizes the significance of the functional distribution of income, and it can be augmented to include concern with the size distribution of income across households (Palley, 2012b). In the Kaleckian model, inappropriate income distribution can produce demand shortage and unemployment. In the short-term, as in the Keynesian 
model, expansionary fiscal policy can increase demand and remedy the problem because government spending is a perfect substitute for private spending. However, higher government spending implies higher taxes to balance the full employment budget and that may have adverse supply-side tax effects that are not present in either Keynesian or Kaleckian models.

Another problem, that may express itself over a longer time period, is a tendency for government spending to ratchet up (Peacock and Wiseman, 1961). Using money financed government spending to offset macroeconomic fluctuations might amplify tendencies in this direction, with potential attendant affects for growth and productivity.

These last two observations, about supply-side and ratchet effects, lead in the direction of a deeper critique of both Keynesianism and MMT. In effect, MMT claims money financed Keynesian fiscal policy can solve the problems of capitalism and deliver full employment and price stability. Starting from a Kaleckian position regarding the centrality of income distribution for full employment, I (Palley, 1998, 2012c) have argued for a "structural Keynesian" approach. The argument is full employment requires not just Keynesian demand management, but also structural policies that address labor market bargaining power concerns and international economic concerns unleashed by globalization. There are two aspects to the argument. First, if flawed income distribution is the cause of the problem, then policy should tackle the underlying problem rather than paper it over with fiscal policy. Second, attempts to paper it over are unlikely to be successful. Over time the problem of flawed income distribution will keep reasserting itself, causing either a retreat into stagnation or an unstable cycle of fiscal intervention. 
Finally, this structural Keynesian position has been criticized as too optimistic by Foster and McChesney (2010). They reiterate the argument of Magdoff and Sweezy (1983) that capitalism has an in-built genetic tendency to stagnation with unemployment and inequality. From their analytic perspective, patches like fiscal policy certainly cannot solve the problem, and nor can even more radical interventions such as those envisioned in the structural Keynesian program. That said, the Magdoff - Sweezy position shares with structural Keynesianism a skepticism about the ability of fiscal policy to solve deeprooted structural imbalances.

\section{MMT and interest rate policy}

It is now time to turn to MMT's interest rate policy recommendation that has already been referred to. According to MMT (Wray, 1998, p.87) the natural rate of interest is zero. Moreover, Wray (2007, p.138) also writes that a monetary policy rule is preferred to policy discretion and that central banks should "set the overnight rate at zero, and keep it there. A properly programmed "tin man" robot ought to do the trick." This claim regarding the natural rate of interest being zero has also been made by Mosler and Forstater (2005).

The logic of MMT's interest rate policy recommendation is as follows. First, as a sovereign money issuer, government does not need to borrow money and pay interest to finance the budget deficit as it can just issue money. In that case, why pay interest at all? Instead, just set the interest rate equal to zero and park it there.

With the interest rate discarded, government uses fiscal policy to stabilize the economy. As discussed earlier, MMT's implicit macroeconomic model is the income expenditure model. Fiscal policy is therefore used to ensure that aggregate demand equals 
full employment output $\left(\mathrm{AD}=\mathrm{y}^{*}\right)$. If $\mathrm{AD}<\mathrm{y}^{*}$, policymakers (who recognize the assignment problem discussed earlier) should increase G, financed by printing money. If $A D>y^{*}$, policymakers should reduce $G$, which reduces the budget deficit. Finally, if AD $=\mathrm{y}^{*}$, policymakers need to ensure a balanced budget to prevent the money supply from continuing to increase and causing inflation. Policymakers (who again recognize the assignment problem) should raise taxes to close the deficit. ${ }^{18}$ In this fashion, the economy is directed to full employment output with a zero interest rate. Ergo, the natural rate of interest is zero.

What is wrong with the story? First, as noted earlier, the MMT model lacks a theory of inflation and a Phillips curve. However, inflation will undoubtedly be positive at full employment. With the short-term policy interest rate set equal to zero, that will imply a significant negative real interest rate. That in turn will spur massive borrowing, particularly to finance asset purchases, unleashing more inflation and asset price bubbles. A zero nominal interest rate at full employment is therefore likely to generate instability. The reason it does not in the MMT model is MMT's "on-off" theory of inflation whereby the inflation "on" switch is only triggered beyond full employment.

Second, MMT's "park it" policy approach to interest is likely to cause significant dislocation and frictional unemployment. "Park it" policy puts the onus of macroeconomic stabilization on fiscal policy, and the assignment rule means stabilization must be done by variation of $\mathrm{G}$. When $\mathrm{AD}>\mathrm{y}^{*}$, government spending must be cut, causing unemployment among government workers and suppliers. Resources need to be freed up and redirected to private sector use and that takes time. Activist interest rate

\footnotetext{
${ }^{18}$ Ensuring $\mathrm{AD}=\mathrm{y}^{*}$ and $\mathrm{D}=0$ may requires a bit of fiscal fine tuning with both $\mathrm{T}$ and $\mathrm{G}$ going up. Increased $\mathrm{T}$ closes the budget gap, while further increased $\mathrm{G}$ offsets any negative $\mathrm{AD}$ impact of increased $\mathrm{T}$.
} 
policy works differently. It reins back private demand so that there is no job loss. Reining back demand is more efficient than cutting demand and relocating workers.

Third, a zero interest rate policy potentially undermines the feasibility of the welfare state. Modern social democratic states require a huge chunk of GDP to cover outlays such as governance, defense, infrastructure investment, healthcare, and education. In times when private sector $\mathrm{AD}$ is strong, a zero interest rate could result in excess demand requiring government spending cuts. Recall the MMT policy program requires $\mathrm{y}^{*}$ $=\mathrm{AD}(\mathrm{G}, \mathrm{T}, \mathrm{i})$ and $\mathrm{D}=\mathrm{G}-\mathrm{T}=0$. A zero interest rate $(\mathrm{i}=0)$ increases $\mathrm{AD}$, requiring cuts in spending $(\mathrm{G})$ and taxes $(\mathrm{T})$. Assuming an interior solution exists, it could involve very low $\mathrm{G}$.

Fourth, MMT discards the interest rate as an instrument of policy and instead relies on fine tuning of government spending to maintain full employment and taxes to maintain budget balance. The assumption is that spending and taxes can be adjusted rapidly and their effects kick-in quickly. Yet long ago, Milton Friedman (1961) challenged the validity of these assumptions with his construct of inside and outside lags. The former represent lags regarding time taken to decide and enact policy change: the latter represent lags regarding time for the effects of policy to kick in. These inside and outside lags may be particularly problematic for discretionary fiscal policy and provide an important justification for using counter-cyclical interest rate policy to stabilize the economy. MMT opposes this with its zero interest rate "park it" rule.

Milton Friedman emphasized the technical (time to identify and enact) dimension of inside lags. However, these lags can also be interpreted in political economy terms. Fiscal policy is a politically contested terrain that can produce policy stalemate and delay 
(as shown by the 2012 "fiscal cliff" conflict). That makes it difficult to rely exclusively on fiscal fine tuning to manage the economy. MMT embodies a naive political economy that is blind to this problem.

Fifth, a zero interest rate policy could also pose problems in an open economy context. As noted earlier, small open economies are vulnerable to inflation and negative real income effects transmitted via exchange rate depreciation. Having a zero nominal interest rate in a world of relatively mobile financial capital and in which other countries have positive nominal interest rates, would likely expose economies to financial capital flight and the possibility of damaging exchange rate depreciation.

A sixth reason for activist non-zero interest rate policy is that it provides an additional instrument of macroeconomic policy. The seminal analysis of Poole (1970) shows interest rate policy helps protect the real economy from disturbances originating in the financial sector. The logic is that financial disturbances affect interest rates and asset prices which in turn affect the real economy. Targeting interest rates can therefore prevent financial disturbances from spilling into the real sector. However, the Poole model only incorporates cost of capital impacts on AD. If wealth effects on $\mathrm{AD}$ are included, there may be reason to adjust interest rates to offset the AD impact of fluctuations in financial asset prices. MMT needlessly discards that policy instrument.

Finally, the MMT motive for setting interest rates equal to zero is the euthenasia of the rentier. That is a good motive but setting the nominal interest rate at zero is not the way to go. Instead, income taxes provide a better route. Additionally, there is a case for asset based reserve requirements that are an implicit asset tax (Palley, 2000, 2003, 2004). 
Asset based reserve requirements (ABRR) require financial firms to hold reserves against different classes of assets, with the regulatory authority setting reserve requirements on the basis of its concerns with each asset class. By forcing financial firms to hold reserves, the system requires that they retain some of their funds in the form of non-interest-bearing deposits with the central bank. The implicit cost of forgone interest must be charged against investing in a particular asset category, and it reduces the marginal revenue from that asset type. As a result, by varying the requirement on each asset class, monetary authorities can vary the return on each asset class and thereby manage demands, prices, and yields across asset classes.

In effect ABRR add policy instruments that supplement and strengthen interest rate policy, thereby enhancing policymakers' ability to stabilize and manage financial markets. Most importantly, policy can target specific asset classes by varying the reserve requirement on that class. That enables policymakers to address concerns regarding specific asset classes without raising the general level of interest rates. Moreover, from a public finance perspective, ABRR are particularly desirable as they increase the demand for reserves (i.e. government issued high-powered money). That creates more space for stable non-inflationary money financed budget deficits. MMT-ers should therefore endorse adoption of ABRR.

\section{MMT and the employer of last resort $^{19}$}

The final issue to be discussed is the MMT proposal for a government employer of last resort (ELR) to ensure labor demand adequate for full employment. The ELR

\footnotetext{
${ }^{19}$ Arguments in this section are based on an early critique of mine (Palley, 2001) of MMT and ELR. Sawyer (2003) has also provided an extensive critique of ELR and he argues it is neither the macro nor micro economically efficient way to reach full employment, and nor does it solve the problem of inflation at full employment. Seccarecia (2004) has also offered a critique of ELR that focuses on the failure of ELR to address the distributive problems of the existing system.
} 
scheme has government set an ELR wage and offer an ELR job at that wage to all who want one. Figure 5 provides a partial equilibrium illustration of the ELR proposal. The ELR agency has a perfectly elastic demand for labor at the ELR wage. Private sector labor demand is constrained by inadequate $\mathrm{AD}$ and is equal to $\mathrm{N}_{\text {Private. }}$. Private sector employment is also assumed to be independent of the real wage. Labor supply is a positive function of the real wage. Given this labor market configuration, ELR employment is equal to the difference between private sector employment and labor supply at the ELR wage.

Figure 5. Partial equilibrium illus tration of the ELR scheme.

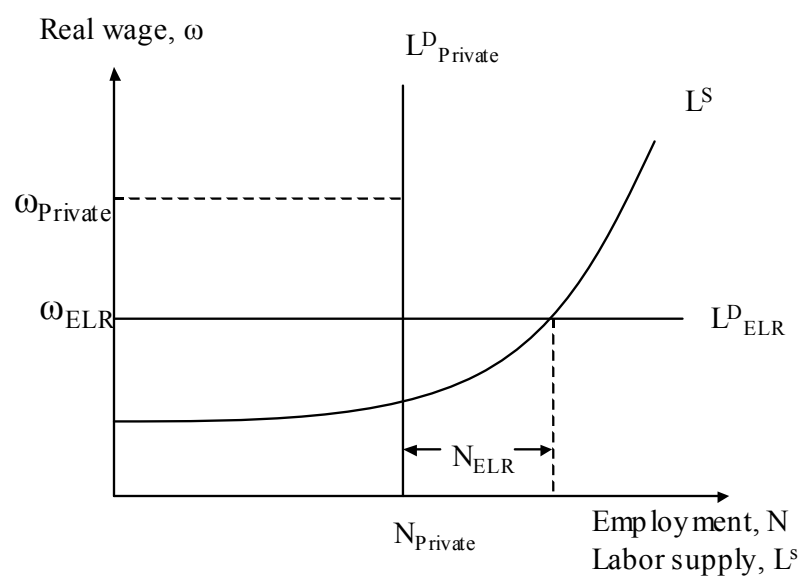

The ELR proposal rests on sound microeconomics, but there are problems regarding its macroeconomics and political economy. With regard to macroeconomics, MMT assumes that government can finance ELR by issuing money without consequence in terms of inflation, macroeconomic stability, or financial cost. The previous sections have shown that this is not the case. There are macroeconomic consequences to issuing money. As regards financial cost, a prudent government is limited in the amount of 
money it issues, and that means ELR expenditures implicitly displace some other expenditures. That displacement may still be worth it but the opportunity cost is nonzero.

The greater concerns about ELR are political. A first political problem concerns the relationship of ELR workers to public sector workers. The ELR wage is set below the market wage in order to avoid drawing labor out of private sector employment and contracting output. Under those conditions it is easy to imagine how anti-worker governments might try to substitute ELR workers for public sector workers, thereby undermining public sector unions and public sector pay. Moreover, weakening the position of public sector workers would likely have adverse spillover effects on the position of private sector workers. Lacking understanding of these effects, many voters would likely support such measures on grounds that it is unjust that one type of public sector worker be paid less than another. Indeed, indications of exactly this type of political outcome are apparent in the U.K. where the Conservative government has recently proposed a variant of the ELR scheme. ${ }^{20}$

A second political problem concerns the relationship between the ELR wage and the minimum wage. The minimum wage is a critical element of fair and well functioning labor markets. The ELR wage must be below the minimum wage to ensure that the minimum wage is binding and that the ELR scheme does not draw labor away from the private sector. That introduces a political tension as to why government should employ

\footnotetext{
${ }^{20}$ See "Million jobless may face six months' unpaid work or have unemployment benefits stopped," The Guardian, Sunday 29 July, 2012. The Conservative's proposed scheme requires unemployed workers to take ELR jobs in order to receive unemployment benefits so that the ELR weekly wage effectively equals unemployment benefit. The Conservative proposal differs from the MMT proposal in that taking ELR jobs is mandatory. In the MMT proposal accepting an ELR job is a voluntary choice and workers continue to receive unemployment benefits even if they decline taking ELR jobs.
} 
workers at less than the minimum wage, and that tension is likely to create pressure to lower the minimum wage to the ELR wage. That would hurt minimum wage workers; hurt all workers by under-cutting the market's wage floor; and contract private sector output by putting minimum wage employment in competition with ELR jobs.

A third political problem is the possibility that ELR work could be used to discredit government. To the extent that ELR work is similar to work done by public sector workers, it increases the threat to public sector unions and wages. To the extent that the work is significantly different, it is likely that it will partake of unproductive or make-work activity. Such instances of make-work activity are then likely to be used by neoliberal politicians to attack government in general.

When it comes to policy there is always need to consider political consequences. MMT is politically naive with regard to ELR. Balanced against that, it is important not to let the perfect be the enemy of the good. Nor should fear of neoliberal reaction be a veto on progressive policy. ELR involves difficult calls of political judgment. It is not the selfevident boon that MMT-ers assert it to be.

\section{Conclusion: MMT as modern money tree economics}

This paper has examined the theory and policy recommendations associated with modern monetary theory. MMT analysis is based on the simple well-understood incomeexpenditure model with addition of a government budget restraint that has the central bank finance the deficit. Its claims about the ease of attaining non-inflationary full employment via money financed budget deficits ignore the challenges posed by Phillips curve analysis, open economy considerations, and financial stability concerns. The oversimplification of the macroeconomic policy challenge is accompanied by an unwarranted 
policy recommendation that central banks set the overnight nominal interest rate at zero and hold it (park it) there. These theoretical and policy failings are compounded by naive political judgment regarding the possibilities of fiscal fine tuning and the political economy implications of ELR for public sector employment.

In the current moment of high unemployment, MMT makes a valuable contribution as part of the rhetoric of advocacy for expansionary policy. However, as regards macroeconomic theory, MMT adds nothing new warranting its own theoretical label. Instead, its over-simplifications represent a step-back in understanding. In physics, the crank physicist is drawn to the idea of a perpetual motion machine that denies the effects of friction. In economics, the crank economist is drawn to the idea of a money tree that voids financial constraints and macroeconomic trade-offs. MMT constitutes a form of modern money tree economics. 


\section{References}

Blinder, A.S., and Solow, R.M. (1973) Does fiscal policy matter? Journal of Public Economics, 2, 319-337.

Cagan, P. (1956), "The monetary dynamics of hyperinflation," in M. Friedman (ed.), Studies in the Quantity Theory of Money, Chicago: University of Chicago Press.

Christ, C.F. (1968), "A simple macroeconomic model with a government budget restraint," Journal of Political Economy, 76, 53-67.

Cripps, T.F. and Godley, W. (1978), "Control of imports as the means to full employment and the expansion of world trade: The U.K.'s case," Cambridge Journal of Economics, 2, $327-334$.

Fiebiger, B. (2012), "Modern money and the real world of accounting: The U.S. Treasury does not spend as per a bank" in "Modern monetary theory: a debate," Working Paper No. 279, Political Economy research Institute, University of Massachusetts, Amherst, MA.

Foster, J.B. and McChesney, R.W. (2010), “Listen Keynesians, it's the system!” Monthly Review, 61 (April), $44-56$.

Forstater, M. and Mosler, W. (2005), “The natural rate of interest is zero," Journal of Economic Issues, XXXIX (2), 535 - 542.

Friedman, M. (1961), "The Lag in Effects of Monetary Policy," Journal of Political Economy, 69 (October).

Godley, W. and Lavoie, M. (2007), Monetary Economics: An Integrated Approach to Credit, Money, Income, Production and Wealth (London: Palgrave/Macmillan).

Greenspan, A. (1997), "Opening remarks," in Managing Financial Stability in a Global Economy, The Federal Reserve Bank of Kansas City, August, 1 - 6.

Hoexter, M., (2013), "Our leaders are mistaking the modern money system for a fistful of dollars - Part 1," New Economic Perspectives, January 20, 2013. Available at: http://neweconomicperspectives.org/2013/01/our-leaders-are-mistaking-the-modernmoney-system-for-a-fistful-of-dollars-part-1.html\#comments.

Keynes, J.M. (1930 [1976]), A Treatise on Money, Volumes I and II, New York: Harcourt-Brace-Jovanovich.

Knapp, G.F. (1924 [1973]), The State Theory of Money, Clifton, New York: Augustus M. Kelley. 
Krugman, P. and Taylor, L., "Contractionary effects of devaluation," Journal of International Economics, 8, 445 - 456.

Lavoie, M. (2011), "The neo-Chartalist view of money: A friendly critical look," unpublished paper, Department of Economics, University of Ottawa.

Magdoff, H. and Sweezy, P.M. (1983), “Listen Keynesians," Monthly Review, 8 (January), $1-11$.

Nordhaus, W.D. (1975), “The political business cycle,” Review of Economic Studies, 42 (April), $169-190$.

Palley, T. I. (1998) Plenty of Nothing: The Downsizing of the American Dream and the Case for Structural Keynesianism, Princeton: Princeton University Press, 1998.

(2000), "Stabilizing finance: The case for asset based reserve requirements," Financial Markets and Society, The Financial Markets Center, Philomont, VA, August.

(2001), “Government as Employer of Last Resort: Can it Work?” Industrial Relations Research Association, 53 ${ }^{\text {rd }}$ Annual Proceedings, 269 - 274.

(2003), "Asset price bubbles and the case for asset based reserve requirements," Challenge, 46 (May - June), 53 - 72.

(2004), "Asset based reserve requirements: Reasserting domestic monetary control in an era of financial innovation and instability," Review of Political Economy, 16 (January), $43-58$.

(2012a), "Monetary Policy and Central Banking after the Crisis: The Implications of Rethinking Macroeconomic Theory," in The Handbook on Political Economy of Financial Crises, Editors: Gerald Epstein and Martin Wolfson, Oxford: Oxford University Press, 624 - 643.

------------ (2012b) "A neo-Kaleckian - Goodwin model of capitalist economic growth: Monopoly power, managerial pay, and labor market conflict," Cambridge Journal of Economics, forthcoming.

(2012c), From Financial Crisis to Stagnation: The Destruction of Shared Prosperity and the Role of Economics, Cambridge: Cambridge University Press.

Peacock, A.T. and Wiseman, J. (1961), The Growth of Public Expenditure in the United Kingdom, Princeton: Princeton University Press.

Poole, W. (1970), 'Optimal choice of monetary policy instruments in a simple stochastic macro model', Quarterly Journal of Economics, 84, 197 - 216. 
Rochon, L.P. and Vernengo, M. (2003), "State money and the real world: or Chartalism and its discontents," Journal of Post Keynesian Economics, 26 (1), 57 - 67.

Sawyer, M. (2003), "Employer of last Resort: Could it deliver full employment and price stability?” Journal of Economic Issues, XXXVII (4), 881 - 907.

Seccarecia, M. (2004), "What type of full employment? A critical evaluation of the government as employer of last resort policy proposal," Investigacion Economica, LXIII, $15-43$.

Tobin, J. (1961), "Money, Capital, and Other Stores of Value," American Economic Review, 51: $26-37$.

-------- (1969), “A general equilibrium approach to monetary theory," Journal of Money, Credit and Banking, 1, 15-29.

(1982), "Money and finance in the macroeconomic process," Journal of Money, Credit and Banking, 14: 171 - 204.

Tobin, J. and Buiter, W.H. (1976), "Long run effects of fiscal and monetary policy on aggregate demand," in J.L. Stein (ed.), Monetarism, (Amsterdam: North Holland).

Tobin, J. and Haliossos, M. (1990), “The macroeconomics of government finance," in Friedman B.M. and Hahn F.H. (eds), Handbook of Monetary Economics, Volume 2, North-Holland: New York.

Tobin, J. and Golub, S. (1998), Money, Credit, and Capital, Boston, MA: Irwin McGrawHill.

Wray, L.R. (1998), Understanding Modern Money: The Key to Full Employment and Price Stability, Edward Elgar: Cheltenham, U.K.

(2007), “A Post Keynesian view of central bank independence, policy targets, and the rules versus discretion debate," Journal of Post Keynesian Economics, 30 (1), $119-141$.

(2012), “A meme for money,” Working Paper No. 736, Levy Economics

Institute of Bard College, November 2012. 
Publisher: Hans-Böckler-Stiftung, Hans-Böckler-Str. 39, 40476 Düsseldorf, Germany Phone: +49-211-7778-331, IMK@boeckler.de, http://www.imk-boeckler.de

IMK Working Paper is an online publication series available at: http://www.boeckler.de/imk 5016.htm

ISSN: $1861-2199$

The views expressed in this paper do not necessarily reflect those of the IMK or the Hans-Böckler-Foundation.

All rights reserved. Reproduction for educational and non-commercial purposes is permitted provided that the source is acknowledged. 